\title{
EFFECT OF SALICYLIC ACID AND ABSCISIC ACID ON MORPHO-PHYSIOLOGICAL AND ANATOMICAL CHARACTERS OF FABA BEAN PLANTS (Vicia faba L.) UNDER DROUGHT STRESS
}

Abdelaal, Kh.A.A.

Agricultural Botany Dept., Fac. of Agric. Kafrelsheikh Univ., Egypt.

E-mail: khaled_elhaies@yahoo.com

\begin{abstract}
Two pot experiments were carried out during the two winter seasons of 2013/2014 and 2014/2015 under greenhouse conditions at the Department of Agricultural Botany, Faculty of Agriculture, Kafrelsheikh University, Egypt to investigate the influence of salicylic acid $(1 \mathrm{mM})$ and abscisic acid $(0.1 \mathrm{mM})$ on morpho-physiological characters and anatomical structure as well as yield characters of faba bean plants under drought stress. As a result of stress only, all studied morphological and anatomical characters as well as chlorophyll concentrations and yield components were decreased, whereas, electrolyte leakage was increased under drought stress. However, application of salicylic acid (SA) and abscisic acid (ABA) under drought stress significantly improved or increased all the mentioned characters except electrolyte leakage which was decreased. Application of SA and ABA under drought stress enhanced the anatomical characters of faba bean stem and leaflets, for instance, stem diameter, number of vessels/bundle in stem as well as leaf lamina thickness and average diameter of xylem vessel. Accordingly, the exogenous application of SA and ABA lead to minimize the harmful effect of drought stress and improve the morpho-physiological characters, stem and leaflets anatomy as well as yield components of faba bean plants even under drought stress.
\end{abstract}

Keywords: Vicia faba L., Drought, Salicylic acid (SA), Abscisic acid (ABA), Physiology, Anatomy, Productivity.

Abbreviations: Salicylic acid (SA), Abscisic acid (ABA), peroxidase (POD), catalase $(\mathrm{CAT})$, Superoxide dismutase (SOD), reactive oxygen species (ROS).

\section{INTRODUCTION}

Faba bean (Vicia faba L. var. faba) belongs to the family Fabaceae and is one of the most important leguminous crops in Mediterranean Sea region. In Egypt, it is a major source of protein for human food and animal feeding and fits well to the low fertility soils of the region. Drought is one of the most environmental stresses threatening the crop production and the major causes of crop loss worldwide, reducing average yields for most major crop plants by more than $50 \%$ (Wang et al., 2003). It is critical factor during the flowering and grain-filling phases in wheat (Farooq et al., 2014). Abdel et al. (2006) found that drought reduced number of leaves, leaf area, number of flowers and pods/plant as well as number of seeds per pod in faba bean. Photosynthesis, respiration, translocation and ion uptake were decreased under drought stress. Drought stress lead to morphological, biochemical and anatomical modifications with a decrease in dry weight and leaf area as well as accumulation of organic compounds like proline and glycine betaine. The 
plant height, chlorophyll content and the growth duration as well as grain yield were decreased under drought stress (Anwar et al., 2015). Under drought stress, Elgmaal and Maswada (2013) found significant increase in electrolyte leakage on maize plant. Siddiqui et al. (2015) reported that drought stress affected growth parameters such as plant dry weight and leaf area in faba bean.

Salicylic acid (SA) is considered as a hormone-like substance and plays an important role in regulation of physiological process such as photosynthesis, ion uptake and transport, stress tolerance as well as membrane permeability (Noreen et al., 2009). Application of salicylic acid at concentration of $50 \mathrm{ppm}$ led to enhancement of the plant growth and development (Azooz and Youssef, 2010), increased resistance to abiotic stresses in many plants and protects the plants from oxidative injury (Moosavi, 2012). Orabi et al. (2010) stated that salicylic acid at concentration of $1 \mathrm{mM}$ regulates physiological adaptation and protects the plant from oxidative damage with an increase in antioxidant enzyme activities and a decrease in ROS level and lipid peroxidation. Application of SA protects the plants against abiotic and biotic stress as well as improves the plant growth and development (Hayat et al., 2010). In mung bean plants under drought stress, SA treatment led to increase plant height, number of pods and seeds/plant as well as 100 seeds weight (Ali and Mahmoud 2013). Foliar application of $1 \mathrm{mM}$ SA caused an increase in chlorophyll a, b, carotenoids and total pigments of faba bean (Azooz et al., 2011). Application with SA at concentration of $0.5 \mathrm{mM}$ significantly decreases the harmful effect of drought stress in wheat seedling (Kang et al., 2013), and also decreases electrolyte leakage in maize plants under salinity stress (Gunes et al., 2007).

Abscisic acid (ABA) is an important plant hormone that plays a key role in plant signaling system which helps the plant to perform function normally under water stress conditions ( $\mathrm{Ma}$ et al., 2008). ABA play important roles in many physiological processes such as seed dormancy, induces stomatal closure, synthesis of storage proteins and lipids and defense against biotic factors. Under drought stress conditions the rates of $\mathrm{ABA}$ and electrolyte leakage were increased, while relative water content was decreased. Application of ABA at concentration of $10 \mu \mathrm{g} \mathrm{I}^{-1}$ led to increase in drought resistance on stressed faba bean plant (Abdel and El-Hamadany, 2010). ABA is produced in the guard cells and induces stomatal closure under drought stress (Lee and Luan, 2012) and significantly enhances the antioxidant enzymes activity in maize under water stress. It was established that the application of $A B A$ increases tolerance to chilling stress by increasing superoxide dismutase and guaiacol peroxidase activities and related gene expression (Guo et al., 2012). Exogenously ABA at concentration of $100 \mu \mathrm{M} / \mathrm{L}$ protects maize plants against the drought stress (Zhang et al. 2012). Application of ABA and Proline in combination was more effective and improved growth parameters of faba bean (Ali et al., 2013). Electrolyte leakages of pretreated citrus leaves with ABA were decreased under freezing stress (Yang et al., 2013). The harmful effects of drought stress decreases with ABA treatment on Pisum sativum (Latif, 2014). ABA can be used 
to minimize the harmful effects of drought stress and regulates many processes in plant in addition to adaptation to biotic and abiotic stresses (Lim et al., 2015).

Therefore, this investigation was designed to enhance the morphophysiological, anatomical and yield characters of faba bean plants with foliar spray with $1 \mathrm{mM}$ of $\mathrm{SA}$ and $0.1 \mathrm{mM}$ of $\mathrm{ABA}$ under drought stress.

\section{MATERIALS AND METHODS}

Two pot experiments were conducted during the two successive winter seasons of 2013/2014 and 2014/2015 under greenhouse conditions of Agricultural Botany Department, Faculty of Agriculture, Kafrelsheikh University, Egypt to study the effect of foliar spray with salicylic acid (SA) and Abscisic acid (ABA) on morpho-physiological and yield characters as well as anatomical structure of faba bean plant (Vicia faba L.) grown under water deficit stress. Plastic pots used in this investigation were $40 \mathrm{~cm}$ in diameter; each pot was filled with $10 \mathrm{~kg}$ clay soil. Seeds of faba bean Sakha 1 were obtained from Division legumes, Agricultural Research Station, Sakha, Egypt and sown on $21^{\text {th }}$ October in the first season and $23^{\text {rd }}$ October in the second one. Five seeds were sown in each pot and after 21 days from sowing, the seedlings were thinned to leave three seedlings per pot. Each pot was provided with $2 \mathrm{gm}$ calcium superphosphate $\left(15.5 \% \mathrm{P}_{2} \mathrm{O}_{5}\right)$ mixed with the soil before sowing, while ammonium sulphate $(20.5 \% \mathrm{~N})$ at the rate of $1 \mathrm{gm}$ was added with the first irrigation and $1 \mathrm{gm}$ potassium sulphate $\left(48 \% \mathrm{~K}_{2} \mathrm{O}\right)$ was added after flowering. Other agricultural practices were done according to the recommended practices for faba bean in the vicinity. The irrigation intervals were 4 days, considered as a control (well watered), 7 days and 15 days. SA at concentration of $1 \mathrm{mM}$ and $\mathrm{ABA}$ at concentration of $0.1 \mathrm{mM}$ were sprayed twice at 30 and 40 days from sowing date.

Soil samples were taken for conducting some physical and chemical analysis according to A.O.A.C. (2005) and all data were shown in Table 1.

Table 1. Physical and chemical soil characteristics during both growing seasons.

\begin{tabular}{|l|c|c|}
\hline Soil analysis & $\mathbf{2 0 1 3 / 2 0 1 4 ~ s e a s o n ~}$ & $\mathbf{2 0 1 4 / 2 0 1 5 ~ s e a s o n ~}$ \\
\hline \multicolumn{3}{|c|}{ Physical analysis } \\
\hline Sand \% & 17.45 & 15.80 \\
\hline Silt\% & 36.55 & 34.90 \\
\hline Clay \% & 46.00 & 49.30 \\
\hline Textural class & Clay & Clay \\
\hline \multicolumn{3}{|c|}{ Chemical analysis } \\
\hline Organic matter $(\%)$ & 1.5 & 1.6 \\
\hline Avialable N (ppm) & 33.5 & 28.65 \\
\hline Avialable P $(\mathrm{ppm})$ & 12.7 & 11.45 \\
\hline Avialable K $(\mathrm{ppm})$ & 291.48 & 292.23 \\
\hline PH & 8.2 & 8.1 \\
\hline
\end{tabular}


The experiment was made in a complete randomized design with three replicates. The treatments were seven as follows:

1-Control, plants irrigated every 4 days (well watered) and untreated with SA or ABA.

2-Plants irrigated every 7 days and untreated with $S A$ or $A B A$.

3-Plants irrigated every 15 days and untreated with $S A$ or ABA.

4-Plants irrigated every 7 days and treated with $S A$ at $1 \mathrm{mM}$.

5 -Plants irrigated every 7 days and treated with $A B A$ at $0.1 \mathrm{mM}$.

6-Plants irrigated every 15 days and treated with $S A$ at $1 \mathrm{mM}$.

7- Plants irrigated every 15 days and treated with $A B A$ at $0.1 \mathrm{mM}$.

Samples were taken for morpho-physiological and anatomical studies at the age of 50 and 75 days from sowing date. Likewise, samples were taken at maturity for yield characters. Data were recorded as follows:

\section{Morpho-physiological and yield characters}

1- Plant height $(\mathrm{cm})$.

2- Number of branches / plant.

3- Number of leaves / plant.

4- Leaf area $\left(\mathrm{cm}^{2} /\right.$ plant).

5- Number of flowers/plant.

6- Number of pods/plant.

7-Number of seeds/pod.

8-100 seeds weight $(\mathrm{g})$.

9- Seed yield (g/plant)

10- Chlorophyll concentrations

Chlorophyll $\mathrm{a}$ and $\mathrm{b}$ concentrations as $\mathrm{mg} / \mathrm{g}$ fresh weight of leaves were extracted. Leaves samples $(0.5 \mathrm{~g})$ were homogenized with acetone $(90 \%$ $\mathrm{v} / \mathrm{v})$, filtered and make up to a final volume of $50 \mathrm{~mL}$. Chlorophyll concentrations were calculated spectrophotometerically from the absorbance of extract at 663 and $645 \mathrm{~nm}$ according to Lichtenthaler (1987).

11- Electrolyte leakage

Twenty leaf discs $\left(1 \mathrm{~cm}^{2}\right)$ of faba bean leaves were taken randomly and placed individually into flasks each contained $25 \mathrm{~mL}$ deionized water. Flasks were shaken for $20 \mathrm{~h}$ at ambient temperature to facilitate electrolyte leakage from tissues. Initial electrical conductivity measurements were recorded for each vial using an Acromet AR20 electrical conductivity meter (Fisher Scientific, Chicago, IL). Flasks were then immersed in a hot water bath (Fisher Isotemp, Indiana, PA) at $80^{\circ} \mathrm{C}\left(176^{\circ} \mathrm{F}\right)$ for $1 \mathrm{~h}$ to induce cell rupture. The vials were again placed on the Innova 2100 platform shaker for $20 \mathrm{~h}$ at $21^{\circ} \mathrm{C}\left(70^{\circ} \mathrm{F}\right)$. Final conductivity was measured for each flask. Electrolyte leakage percentage was calculated as follow:

Initial conductivity/final conductivity $\times 100$ according to Szalai et al. (1996) and as described by Hafez et al. (2014) and Abdelaa et al. (2014).

\section{Anatomical studies}

For anatomical studies, specimens $1 \mathrm{~cm}$ length from selected samples were taken during the second season 2014/2015 from the middle of fifth internode from stem tip and the fifth leaf (leaflet including the midrib $0.5 \mathrm{~cm}$ length) of faba bean plant at the age of 50 days from sowing. Samples were 
killed and fixed for at least $48 \mathrm{~h}$ in F.A.A. solution ( $5 \mathrm{ml}$ glacial acetic acid, 10 $\mathrm{ml}$ formalin and $85 \mathrm{ml}$ ethyl alcohol $70 \%$ ). Samples were washed in $50 \%$ ethyl alcohol and dehydrated in a normal butyl alcohol series. The specimens were impeded in paraffin wax $\left(56-58^{\circ} \mathrm{C}\right)$. Transverse sections $(15$ microns) thick were done with rotary microtome model 820 , paraffin sections were fixed on the slides with albumin, stained with safranin light green combination and mounted in Canada balsam (Nassar and El-Sahhar, 1998). Slides were examined microscopically and photomicrographed.

\section{Statistical analysis:}

The obtained data for each studied character were subjected to appropriate statistical analysis according to O'Mahony (1986).

\section{RESULTS AND DISCUSSION}

\section{Morphological characters of vegetative growth}

The effects of SA and ABA on plant height, number of branches, number of leaves/plant and leaf area $\left(\mathrm{cm}^{2}\right) /$ plant of faba bean plants under drought stress are shown in Figure 1. Drought stress caused significant decreases in plant height, number of branches and leaves/plant as well as leaf area (Figure $1 \mathrm{~A}, \mathrm{~B}, \mathrm{C}$ and $\mathrm{D}$ ) in both seasons. This reduction in growth parameters may be due to the reduction of water flow from the xylem to the different cells, which regulates cell division, elongation and development as well as the decline in chlorophyll content and lipid peroxidation in the cell membrane.

These results are similar to those reported by (Hassan et al., 2011; Farooq et al., 2014 and Anwar et al., 2015). Interestingly enough that the maximum values of plant height, number of branches, number of leaves/plant and leaf area $\left(\mathrm{cm}^{2}\right)$ / plant were obtained with application of SA at $1 \mathrm{mM}$ and ABA at $0.1 \mathrm{mM}$ on faba bean plants irrigated every 15 days, while the lowest values of studied characters were recorded on plants which irrigated every 15 days and untreated with SA or ABA in both seasons. The pivotal role of SA on growth characters may be due to enhance activity of antioxidant enzyme which protects the plants from the oxidative damage, reducing ROS levels and lipid peroxidatin as well as ion leakage (Nazar et al., 2011). These results were in conformity with the observation of many researchers (Azooz, 2009 in faba bean and Aldesuquy et. al., 2013 in wheat). The presented data in Figure $1(A, B, C$ and $D)$ indicated the enhancement effect of $A B A$ on plant height, number of branches, number of leaves and leaf area of faba bean plants under drought stress. This effect could be attributed to improve antioxidant enzyme activities such as CAT and increase proline content as well as induces stomatal closure to conserve water in the plant organs. Our results were supported by the obtained results with Guo et al. (2012); Yang et al. (2013) and Lim et al. (2015). 


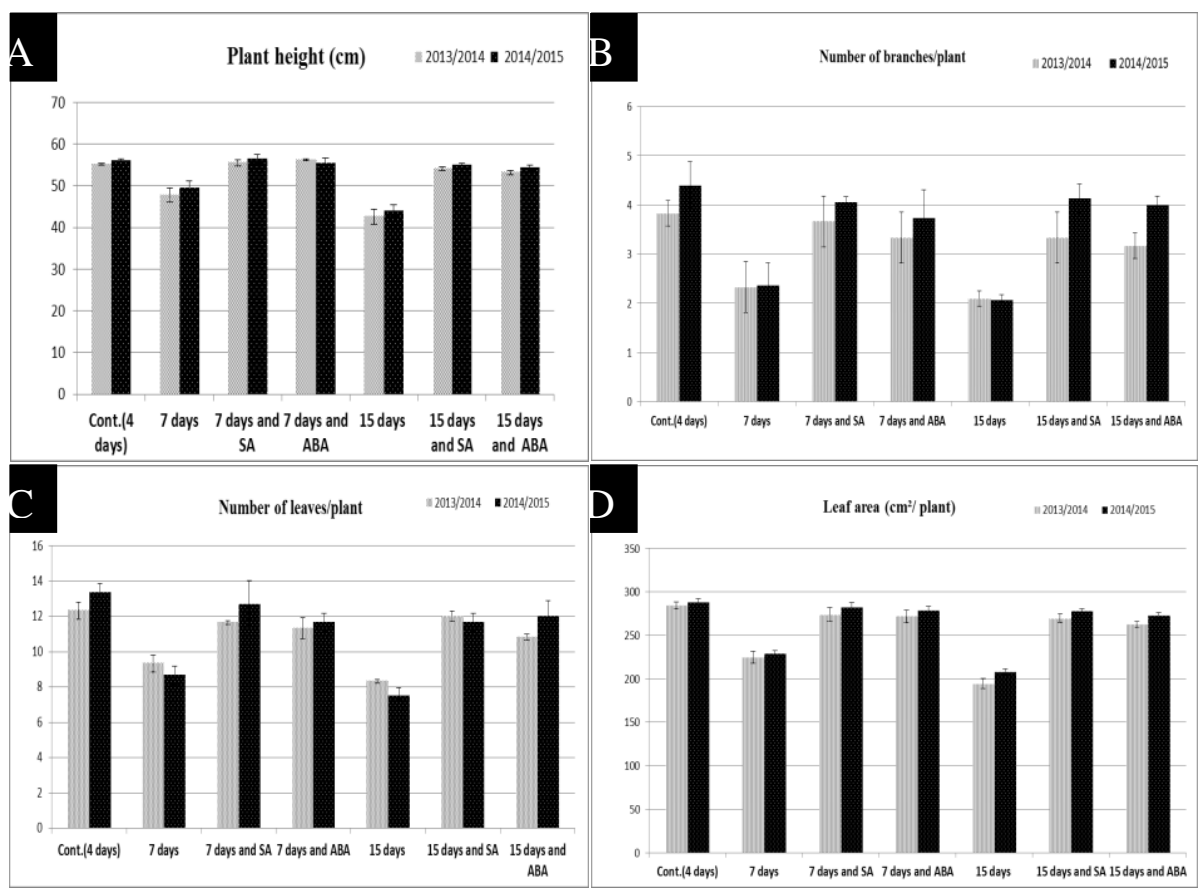

Fig. 1: Plant height, number of branches and leaves and leaf area of faba bean plants affected with salicylic acid and abscisic acid under drought stress during the two seasons 2013/2014 and 2014//2015

Details:- Control (4 days) (plants irrigated every 4 days and untreated with SA or ABA), 7 days (plants irrigated every 7 days and untreated with SA or ABA), 7 days and SA (plants irrigated every 7 days and treated with SA at $1 \mathrm{mM}$ ), 7 days and ABA (plants irrigated every 7 days and treated with $A B A$ at $0.1 \mathrm{mM}$ ), 15 days (plants irrigated every 15 days and untreated with SA or ABA), 15 days and SA (plants irrigated every 15 days and treated with $S A$ at $1 \mathrm{mM}$ ), 15 days and ABA (plants irrigated every 15 days and treated with $A B A$ at $0.1 \mathrm{mM}$ ).

\section{Yield characters}

Data presented in Figure 2 ( $A, B, C, D$ and $E)$ cleared that drought stress significantly decreased number of flowers and pods/plant, number of seeds/pod and 100 seeds weight $(\mathrm{g})$, as well as seed yield (g/plant), whereas application of $\mathrm{SA}$ at $1 \mathrm{mM}$ and $\mathrm{ABA}$ at $0.1 \mathrm{mM}$ led to increases in these parameters of faba bean plant under drought stress in both seasons. The deleterious effect of drought on flowers number and pods may be due to the reduction of relative water content, total chlorophyll contents and efficiency of photosynthesis as well as translocation and ion uptake were decreased under drought stress. These results are in harmony with those obtained by Anwar et al. (2015) on faba bean plants. Al-Suhaibani (2009) mentioned that stressed faba bean plant significantly decreased seed weight (g/plant), 100-seed weight (g) and seeds yield (ton/fed). The useful effect of SA improves the relative water content and photosynthesis as well as increases the growth and seeds production on common bean plants 
(Sadeghipour and Aghaei, 2012). In this concern, Hayat et al. (2010) reported that Salicylic acid induce flowering process in many plants. It is documented that application of SA led to increase number of pods and seeds/plant as well as 100 seeds weight of mung bean plants (Ali and Mahmoud 2013). Similar results were recorded by Elgmaal and Maswada (2013) on maize plants. Furthermore, the recorded data also showed that $A B A$ at $10 \mu \mathrm{g} \mathrm{I}^{-1}$ significantly increased number of flowers and pods/plant, as well as number of seeds/pod and 100-seeds weight (g) as well as seed yield (g/plant) in the two growing seasons compared with stressed untreated plants (Fig. 2 A, B, C, D and E), however there were no significant deference when compared with the control. These results may be due to the significant role of $A B A$ to induce stomatal closure, preserve water in plant organs and accumulate of amino acid as well as osmotic adjustment and enhance the antioxidant enzymes activity in many plants under drought stress. These results are in consistency with those reported by Lee and Luan (2012).

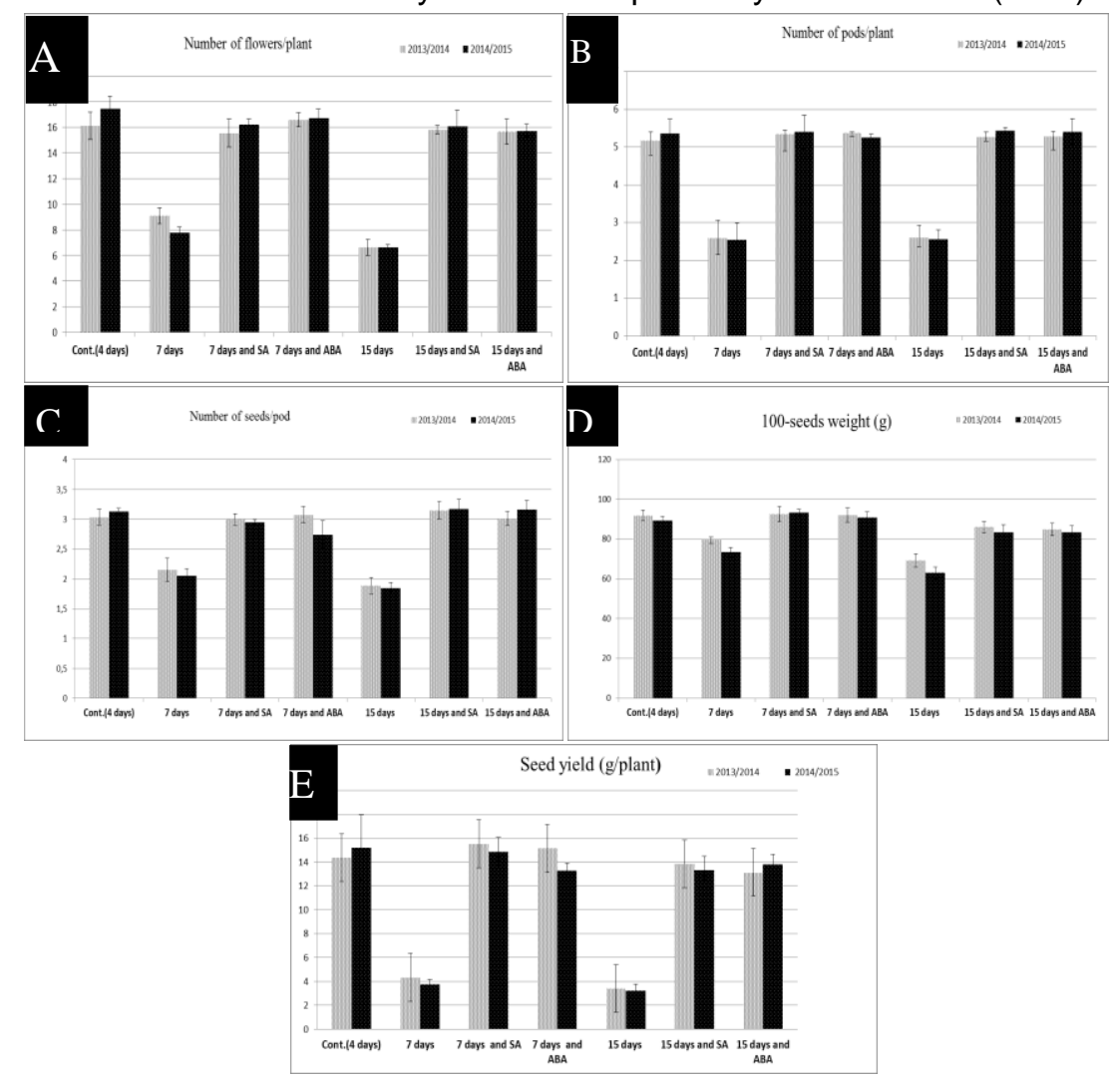

Fig. 2: Number of flowers and pods/plant, number of seeds/pod and 100-seeds weight $(\mathrm{g})$ as well as seed yield ( $\mathrm{g} / \mathrm{plant}$ ) of faba bean plants affected with salicylic acid and abscisic acid under drought stress during the two seasons 2013/2014 and 2014//2015. 


\section{Chlorophyll a, b concentrations and electrolyte leakage percentage}

Referring to the effect of drought stress, data in Figure 3 showed that concentrations of chlorophyll $\mathrm{a}$ and $\mathrm{b}$ in faba bean plants were significantly decreased in plants which irrigated every 7 and 15 days and untreated with SA or ABA in both seasons (Fig. $3 A$ and B). This effect may be due to the reduction in photo-assimilation rate (Matile et al., 1999) and oxidative damage to the chloroplasts as well as decline of the pigment protein complexes, in addition to disorganization of thylakoid membranes, formation of enzymes such as chlorophyllase, which is responsible for degrading chlorophyll (Sidiqii et al., 2015). Similar results were confirmed by Dawood et al. (2014) and Anwar et al. (2015). The presented data also showed significant increases in chlorophyll $a$ and $b$ concentrations in both seasons with treatments of SA and ABA under drought stress compared with control (irrigation every 4 days) and stressed untreated plants (irrigation every 7 and 15 days without SA or ABA treatments). The increases in chlorophyll concentrations were not significantly different between the plant irrigated every 7 and 15 days and treated with SA and ABA. The enhancement of chlorophyll concentrations may be due to the effective role of SA in increment nutrient contents in plant organs as well as improvement some physiological and biochemical processes such as photosynthetic capacity and antioxidant activity as well as increase leaves longevity. These findings correlate with those of Elgmaal and Maswada (2013). On the other hand, Gunes et al. (2007) mentioned that application of SA did not affect total chlorophyll concentrations in maize plants under salinity stress. Under water stress application of ABA lead to increase the chlorophyll concentrations in seedlings of bean, tobacco, beets, and corn (Haisel et al., 2006), The positive effect of ABA may be due to its role in protecting chlorophyll by decreasing chlorophyll degradation and also improves photosystem II and photochemistry (Haisel et al., 2006), as well as induces antioxidant enzymes activity such as catalase, peroxidase and polyphenol oxidase which increases chlorophyll concentrations (Abdelaal et al., 2014 and Hafez et al., 2014).

It is evident from Figure $3 \mathrm{C}$ that electrolyte leakage was increased in stressed untreated faba bean plants compared with control and stressed treated plants with $S A$ and $A B A$. Under drought stress plants produce reactive oxygen species (ROS), which are injurious to plants due to the oxidative stress of cells. Similar results were obtained by many researchers (Gunes et al., 2007) on several plants and Abdelaal et al. (2014) on wheat plants under biotic stress. Application of SA led to significant decreases in electrolyte leakage under drought stress (Gunes et al. (2007). These results may be due to the pivotal role of SA in improving ion uptake, enhancing the function of cell membrane and reducing the harmful effect of stress. These effects of SA on electrolyte leakage are in accordance with those obtained by Elgmaal and Maswada (2013) and Singh et al. (2015) under different stresses. Furthermore, a significant reduction in electrolyte leakage was recorded with $A B A$ treatment under drought stress. In agreement with our findings Yang et al. (2013) reported that exogenously ABA lead to reduce the 
electrolyte leakage in citrus plants under freezing stress, this effect of $A B A$ in reduction of electrolyte leakage may be dye to increase the antioxidant enzyme activities for instance superoxide dismutase (SOD), catalase (CAT), peroxidases (PODs).

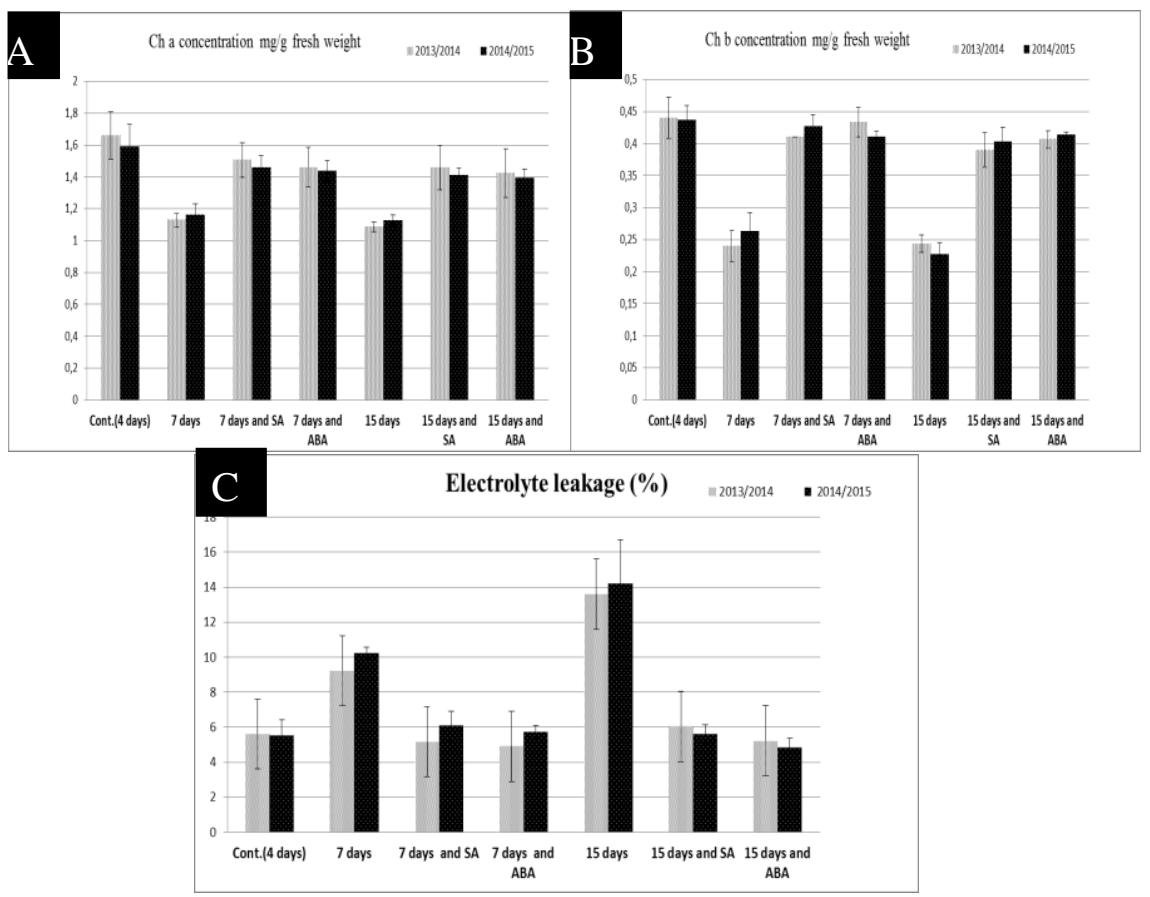

Fig. 3: Chlorophyll a, b concentrations and electrolyte leakage of faba bean plants affected by salicylic acid and abscisic acid under drought stress during the two seasons 2013/2014 and 2014//2015.

\section{Anatomical studies}

\section{Stem anatomy}

It is realized from Table (2) and Figure $4(A-F)$ that the lowest values of stem diameter and cortex thickness of stressed faba bean stem were recorded in the stressed untreated plants (plants irrigated every 7 and 15 days and untreated with $\mathrm{SA}$ or $\mathrm{ABA}$ ) (Fig.4B \& C) in comparing with control (Fig.4A) and stressed treated plants (Fig.4D-F), whereas the best values of stem diameter, cortex thickness, vascular tissues thickness and number of xylem vessels/bundle as well as average diameter of vessel were achieved in the stressed treated plants (plants irrigated every 15 days and treated with $\mathrm{SA}$ at $1.0 \mathrm{mM}$ or $\mathrm{ABA}$ at $10 \mathrm{\mu g}^{-1}$ ) (Fig .4E \& F) compared with control plant and stressed untreated plants (Fig.4A-C). The reduction in anatomical 
characters under drought stress may be due to the harmful effect of water deficit on cell division and expansion as well as nutrient uptake. These results were supported by Guerfel et al. (2009), Makbul et al. (2011) and Reda (2007) under salinity stress. The positive role of SA or ABA on the stem diameter and cortex thickness as well as vascular tissues could be attributed to the increments induced in most tissues.

Table 2. Anatomical characters of faba bean stem under drought stress and affected with salicylic acid or abscisic acid during season 2014/2015.

\begin{tabular}{|c|c|c|c|c|c|}
\hline Treatments & $\begin{array}{c}\text { Stem } \\
\text { diameter } \\
(\mu)\end{array}$ & $\begin{array}{c}\text { Cortex } \\
\text { thickness } \\
(\mu)\end{array}$ & $\begin{array}{c}\text { Vascular } \\
\text { tissue } \\
\text { thickness }(\mu)\end{array}$ & $\begin{array}{c}\text { Number of } \\
\text { vessels/ } \\
\text { bundle }\end{array}$ & $\begin{array}{c}\text { Average } \\
\text { diameter of } \\
\text { vessel }(\mu)\end{array}$ \\
\hline $\begin{array}{l}\text { Control (irrigation } \\
\text { every } 4 \text { days) }\end{array}$ & 927.88 & 108.56 & 167.3 & 14.5 & 10.8 \\
\hline $\begin{array}{l}\text { Plants irrigated } \\
\text { every } 7 \text { days and } \\
\text { untreated with SA } \\
\text { or ABA. }\end{array}$ & 795.93 & v8.01 & 160.3 & 16 & 11.7 \\
\hline $\begin{array}{l}\text { Plants irrigated } \\
\text { every } 15 \text { days and } \\
\text { untreated with SA } \\
\text { or ABA. }\end{array}$ & 760.01 & or.A. & 193 & 17 & 18.4 \\
\hline $\begin{array}{l}\text { Plants irrigated } \\
\text { every } 7 \text { days and } \\
\text { treated with ABA at } \\
10 \mathrm{\mu g} \mathrm{I}^{-1} \text {. }\end{array}$ & 937.78 & 94.9. & 183.3 & 21 & 10 \\
\hline $\begin{array}{l}\text { Plants irrigated } \\
\text { every } 15 \text { days and } \\
\text { treated with SA at } \\
1.0 \mathrm{mM} \text {. }\end{array}$ & 944.5 & 97.75 & 161.8 & 15 & 17.9 \\
\hline $\begin{array}{l}\text { Plants irrigated } \\
\text { every } 15 \text { days and } \\
\text { treated with ABA at } \\
10 \mathrm{\mu g} \mathrm{I}^{-1} \text {. }\end{array}$ & 948 & 117.69 & 170.4 & 16.5 & 15.6 \\
\hline
\end{tabular}

\section{Leaf Anatomy}

Anatomical characters of leaf (leaflet) of faba bean plants grown under drought stress and affected by foliar spraying with $S A$ at $1 \mathrm{mM}$ or $A B A$ at 0.1 $\mathrm{mM}$ were monitored and illustrated in Table 3 and Figure 5 (A-F). The obtained results revealed that drought stress decreased thickness of the leaflet lamina and xylem as well as phloem in midvein bundle (Fig. 5A). This effect of drought stress could be attributed to the decrease induced in the palisade and spongy tissues thickness, as well as in the length and width of midvein bundles. These results are in agreement with those obtaind by Boghdady (2009) in mung bean and Petrov et al. (2012) in barley plants. Data illustrated in Fig. 5 (D-F) showed the important role of SA and ABA treatments in enhancement most of characters of leaflet in stressed faba bean plants irrigated every 15 days and treated with SA or ABA (Fig. 5E and 
F) particularly stem diameter, cortex thickness, vascular tissues thickness and number of xylem vessels/bundle as well as average diameter of vessel.

The pivotal effect of SA and ABA could be attributed to reduce the deleterious effect of drought on the anatomical structure of faba bean. Similar results were recorded by Dawood et al. (2014) on faba bean plants with proline application under salinity stress.

Table 3. Anatomical characters of faba bean leaf (leaflet) under drought stress and affected by salicylic acid or abscisic acid during season 2014/2015.

\begin{tabular}{|l|c|c|c|c|c|}
\hline Treatments & $\begin{array}{c}\text { Thickness of } \\
\text { lamina } \\
(\boldsymbol{\mu})\end{array}$ & $\begin{array}{c}\text { Thickness } \\
\text { of phloem } \\
(\boldsymbol{\mu})\end{array}$ & $\begin{array}{c}\text { Thickness } \\
\text { of xylem } \\
(\boldsymbol{\mu})\end{array}$ & $\begin{array}{c}\text { No. of } \\
\text { xylem } \\
\text { rows/ } \\
\text { midvein } \\
\text { bundle }\end{array}$ & $\begin{array}{c}\text { No. of } \\
\text { vessels/ } \\
\text { midvein } \\
\text { bundle }\end{array}$ \\
\hline $\begin{array}{l}\text { Control (irrigation } \\
\text { every 4 days) }\end{array}$ & 246.08 & 39.92 & 68.15 & 6 & 18 \\
\hline $\begin{array}{l}\text { Plants irrigated } \\
\text { every } 7 \text { days and } \\
\text { untreated with SA } \\
\text { or ABA. }\end{array}$ & 216.39 & 63.57 & 49.65 & 7 & 21 \\
\hline $\begin{array}{l}\text { Plants irrigated } \\
\text { every 15 days and } \\
\text { untreated with SA } \\
\text { or ABA. }\end{array}$ & 208.39 & 54.12 & 55.03 & 5 & 16 \\
\hline $\begin{array}{l}\text { Plants irrigated } \\
\text { every 7 days and } \\
\text { treated with ABA at } \\
10 \mu g \text { I }^{-1} \text {. }\end{array}$ & 256.67 & 36.87 & 78.11 & 5 & 18 \\
\hline $\begin{array}{l}\text { Plants irrigated } \\
\text { every 15 days and } \\
\text { treated with SA at } \\
1.0 \text { mM. }\end{array}$ & 275.14 & 26.87 & 93.01 & 7 & 27 \\
\hline $\begin{array}{l}\text { Plants irrigated } \\
\text { every 15 days and } \\
\text { treated with ABA at } \\
10 \mu g \text { I }^{-1} \text {. }\end{array}$ & 250.69 & 46.01 & 73.68 & 8 & 28 \\
\hline
\end{tabular}



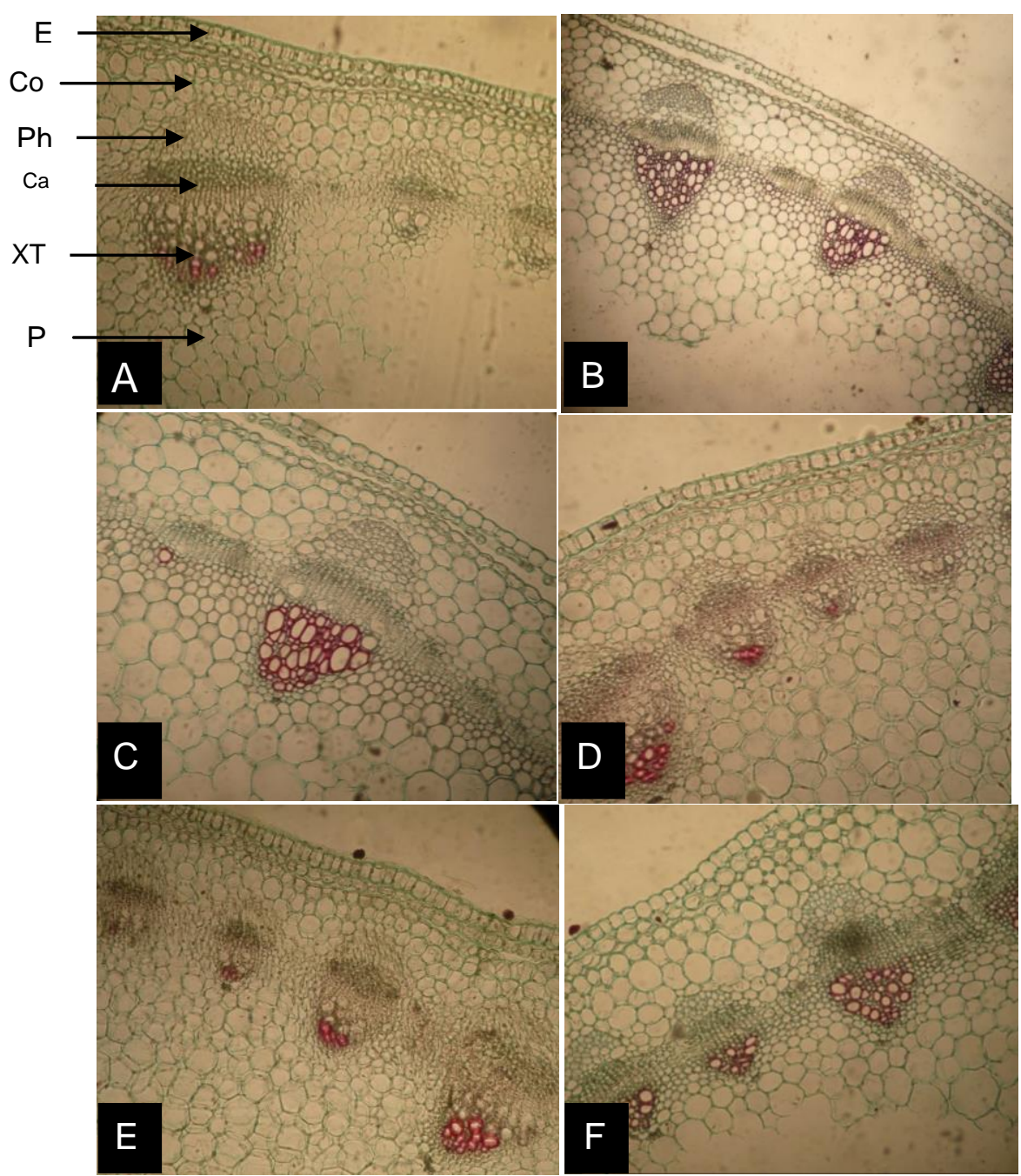

Fig.4: Transverse sections of faba bean stem. A: control (plants irrigated every 4 days), B: plants irrigated every 7 days and untreated with SA or ABA. C: Plants irrigated every 15 days and untreated with SA or ABA. D: Plants irrigated every 7 days and treated with $A B A$. E: Plants irrigated every 15 days and treated with SA. F: Plants irrigated every 15 days and treated with ABA. (X 100).

Details:- E: Epidermis, Co: cortex, Ph T: Phloem tissue, Ca: cambium, X T: Xylem tissue, P: pith 


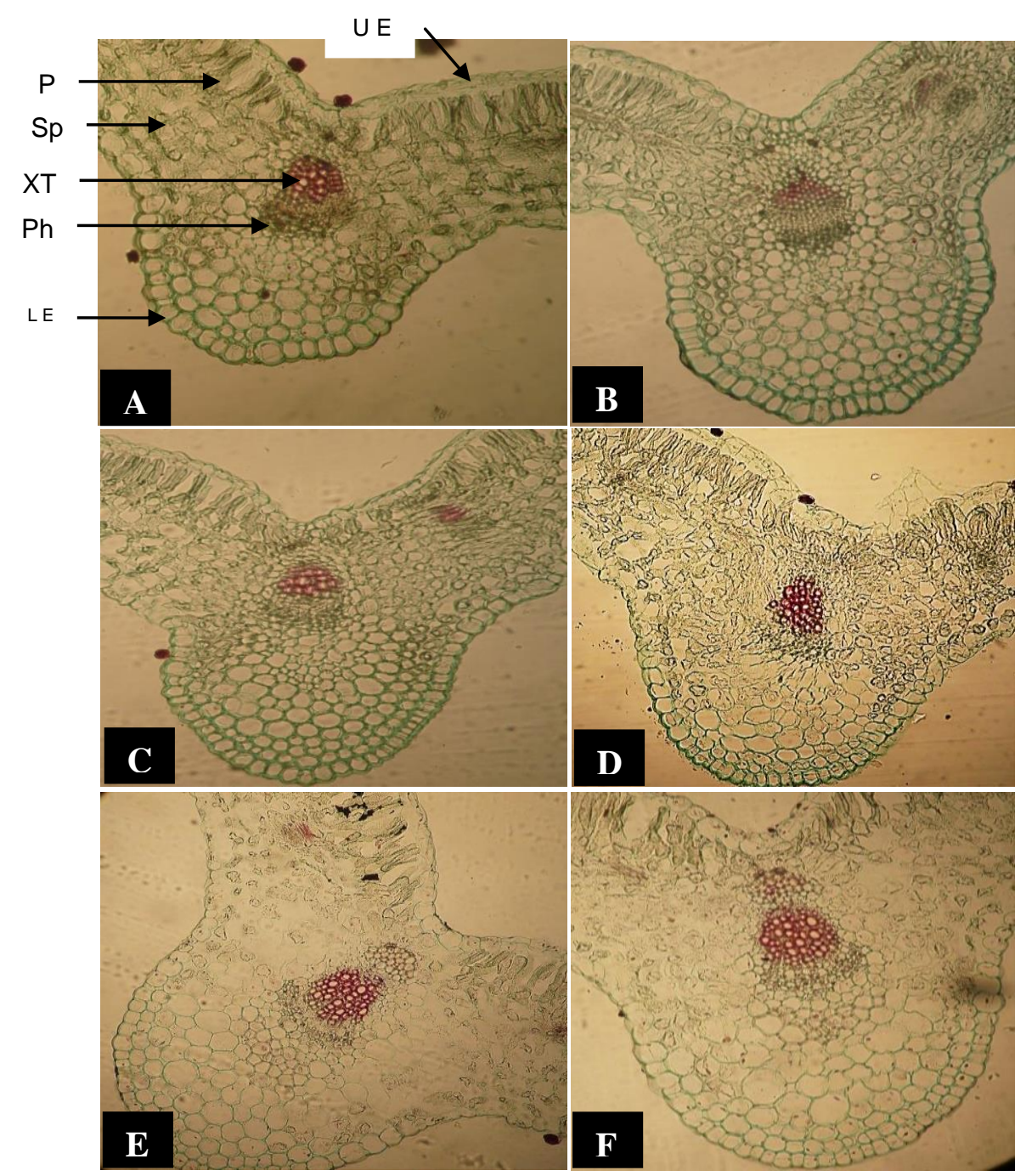

Fig.5: Transverse sections of faba bean leaf (leaflet). A: control (plants irrigated every 4 days), B: plants irrigated every 7 days and untreated with SA or ABA. C: Plants irrigated every 15 days and untreated with SA or ABA. D: Plants irrigated every 7 days and treated with ABA. E: Plants irrigated every 15 days and treated with SA. F: Plants irrigated every 15 days and treated with ABA. (X 100).

Details: U E: Upper epidermis, P T: Palisade tissue, Sp T: Spongy tissue, X T: Xylem tissue, Ph T: Phloem tissue, L E: Lower epidermis. 


\section{Aknowledgement}

This research was supported by Plant Pathology and Biotechnology Lab., (under accreditation of ISO/17025) and EPCRS Excellence Centre, Dept. of Agric. Botany, Fac. of Agric., Kafr-Elsheikh University, Kafr-Elsheikh, Egypt. The EPCRS Excellence Centre Project funded by Management Supporting Excellence (MSE), Development Projects Management Unit, Ministry of Higher Education, Egypt.

\section{REFERENCES}

Abdelaal, Kh. A. A.; Y. M. Hafez; M.M. Badr; W.A. Youseef and Samar, M. Esmail (2014). Biochemical, histological and molecular changes in susceptible and resistant wheat cultivars inoculated with stripe rust fungus Puccinia striiformis f.sp. tritici, Egyptian Journal of Biological Pest Control, 24(1):421-429.

Abdel, C. G. (2006). Improving yield and yield quality of four Faba bean cultivars under rainfalls 1-Application of some inorganic nutrients, Mesopotamia J. of Agric., 34 (4): 12-22.

Abdel, C.G. and S.Y.H. Al-Hamadany (2010). Response of five water stressed Fababean (Vicia faba L.) cultivars to exogenous absiscic acid application. Dohuk Univ. J. Agric. Vet., 13(1), 12.

Abdo, Fatma, A., Dalia, M. A. Nassar, Elham, F. Gomaa and Rania, M. A. Nassar, (2012). Minimizing the harmful effects of Cadmium on vegetative growth, leaf anatomy, yield and physiological characteristics of Soybean plant [Glycin max L.) Merrill] by foliar spray with active yeast extract or with garlic cloves extract. Research Journal of Agriculture and Biological Science, 8(1): 24-35.

Aldesuquy, Heshmat S.; M. A. Abbas; S. A. Abo-Hamed and Abeer H. Elhakem, (2013). Does Glycine betaine and Salicylic Acid ameliorate the negative effect of drought on wheat by regulating osmotic adjustment through solutes accumulation? Journal of Stress Physiology \& Biochemistry, 9 (3): 5-22.

Ali, E.A. and A. M. Mahmoud, (2013). Effect of foliar spray by different salicylic acid and zink concentrations on seed yield and yield components of mung bean in sandy soil. Asian J. Crop Sci., 5(1): 33-40.

Ali, H. M.; M. H Siddiqui; M. H. Al-Whabi; M. O. Basalah; A. M. Sakran and M. El-Zaidy, (2013). Effect of proline and Abscisic acid on the growth and physiological performance of faba bean under water stress, Pak. J. Bot., 45(3): 933-940.

Al-Suhaibani, N.A. (2009). Influence of early water deficit on seed yield and quality of faba bean under arid environment of Saudi Arabia, AmericanEurasian J. Agric. and Environ. Sci., 5 (5): 649-654.

Anwar, F.; M. H. Ammar; E. H. El-Harty; H. M. Migdadi; S. M. Abdel-Khalik; S. A. Al-Faifi; M. Farooq and S. S. Alghamdi (2015). Physiological and Yield Responses of Faba bean (Vicia faba L.) to Drought Stress in Managed and Open Field Environments, J. Agron. Crop Sci., 201(4):280-287. 
A.O.A.C., (2005). Association of Official Analytical Chemists. Official Methods of analysis, 26th Ed., A.O.A.C. International, Washington, D.C., USA.

Ashraf, M.; N.A. Akram; R .N. Arteca and M.R. Foolad (2010). The physiological, biochemical and molecular roles of brassinosteroids and salicylic acid in plant processes and salt tolerance. Critical Reviews in Plant Sci., 29(3): 162-190.

Azooz, M. M. and M. M. Youssef, (2010). Evaluation of heat shock and salicylic acid treatments as inducers of drought stress tolerance in Hassawi wheat. Amer. J. Plant Physiol., 5: 56 - 70.

Azooz, M. M.; M. A. Youssef and A. Parvaiz, (2011). Evaluation of salicylic acid (SA) application on growth, osmotic solutes and antioxidant enzyme activities on broad bean seedlings grown under diluted seawater, International Journal of Plant Physiology and Biochemistry, 3(14): 253-264.

Boghdady, M.S. (2009). Physiological and Anatomical Studies on Mung Bean Plant Under Salinity Conditions. Ph.D. Thesis Faculty of Agriculture, Zagazig University, Egypt (pp. 222).

Dawood, M. G.; H. A. A. Taie; Rania.M.A. Nassar, M.T. Abdelhamid and U. Schmidhalter,,(2014). The changes induced in the physiological, biochemical and anatomical characteristics of Vicia faba by the exogenous application of proline under seawater stress, South African Journal of Botany 93: 54-63

Elgmaal,, A. A. and H. F. Maswada, (2013). Responce of three yellow maize hybrids to exogenous salicylic acid under two irrigation intervals, Asian J. Crop Scie., 5(3): 264-274.

El-Nagdy, G. A.; Dalia, M. Nassar; Eman, A. Elkady and Gelan, S.A.ElYamanee, (2010). Response of flax plant (Linum usitatissimum L.) to treatments with mineral and bio-fertilizers from nitrogen and phosphorus. Journal of American Science, 6(10): 207-216.

Farooq M.; M. Hussain and K. H. M. Siddique, (2014). Drought Stress in Wheat during Flowering and Grain - filling Periods, Critical Reviews in Plant Sciences, 33:331-349.

Guerfel, M.; O. Baccouri; D. Boujnah; W. Chaibi and M. Zarrouk,(2009). Impacts of water stress on gas exchange, water relasions, chlorophyll contentand leaf structure in the two main Tunisian olives (Olea europaea L.) cultivars. SciHortie, 119:257-263.

Gunes, A.; A. Inal; M. Alpaslan; F. Eraslan; E. Guneri and B. N. Cicek, (2007). Salicylic acid induced changes on some physiological parameters symptomatic for oxidative stress and mineral nutrition in maize (Zea mays L.) grown under salinity, Journal of Plant Physiology, 164: 728-736. 
Guo, W. L.; R. G. Chen; Z. H. Gong; Y. X. Yin; S. S. Ahmedand and Y. M. $\mathrm{He},(2012)$. Exogenous abscisic acid increases antioxidant enzymes and related gene expression in pepper (Capsicum annuum) leaves subjected to chilling stress. Genetics and Molecular Research, 11:4063-4080.

Hafez, Y. M.; R.Y. Mourad; M. Mansour and Kh. A.A. Abdelaal, (2014). Impact of Non-traditional Compounds and Fungicides on Physiological and Biochemical Characters of Barely Infected with Blumeria graminis f. sp hordei under Field Condtitions, Egyptian Journal of Biological Pest Control, 24(1):445-453.

Haisel, D.; J. Pospíšilová; H. Synková; R. Schnablová; P. Bat'ková, (2006). Effects of abscisic acid or benzyladenine on pigment contents, chlorophyll fluorescence, and chloroplast ultrastructure during water stress and after rehydration, Photosynthetica, 44(4):606-614.

Hammerschmidt, R.; E.M. Nuckles and J. Kuć, (1982). Association of enhanced peroxidase activity with induced systemic resistance of cucumber to Colletotrichum lagenarium. Physiol. Plant Pathol., 20(1):73-82.

Hassan, A. I.; Hanan, M. Aou Zeid and J. Basahi, (2011). Photosynthetic response of Egyptian cultivar of broad bean (Vicia faba L.) to UV-B and drought, singly and in combination, International Research Journal of Agricultural Science and Soil Science, 1(11): 455-461.

Hayat, Q.; S. Hayat; M. Irfan and A. Ahmad, (2010). Effect of exogenous salicylic acid under changing environment: A review. Environ. Exp. Bot. 68: 14-25.

Kang, G.Z.; G.Z. Li; G.Q. Liu; W. Xu; X.Q. Peng; C. Y. Wang; Y. J. Zhu and T. C. Guo, (2013). Exogenous salicylic acid enhances wheat drought tolerance by influence on the expression of genes related to ascorbateglutathione cycle, Biologia Plantarum, 57 (4): 718-724.

Latif, H.H. (2014). Physiological responses of Pisum sativum plant to exogenous ABA application under drought conditions. Pak. J. Bot., 46(3): 973-983.

Lee, S.C. and S. Luan, (2012). ABA signal transduction at the crossroad of biotic and abiotic stress responses. Plant Cell Environ., 35:53-60.

Lichtenthaler, H. K. (1987). Chlorophylls and carotenoids: pigments of photosynthetic bio-membranes. Methods Enzymol, 148:350-382.

Lim, C. W.; W. Baek; J. Jung; J. Kim and S. C. Lee, (2015) Function of ABA in stomatal defense against biotic and drought stresses, Int. J. Mol. Sci., 16: 15251-15270.

Ma, X. W.; F.W. Ma; Y. F. Mi; Y. H. Ma, et al. (2008). Morphological and physiological responses of two contrasting malus species to exogenous abscisic acid application. Plant Growth Regul. 56: 77-87.

Makbul, S.; N.G. Saruhan; N. Durmus and S. Guven, (2011) Changes in anatomical and physiological parameters of soybean under drought stress, Turk. J. Bot., 35:369-377.

Matile, P., Hortensteiner, S. and Thomas, H. (1999). Chlorophyll degradation. Annu. Rev. Plant Physiol. Plant Mol. Biol., 50, 67-95. 
Mir, S.; A. Sirousmehr and E. Shirmohammadi, (2015). Effect of nano and biological fertilizers on carbohydrate and chlorophyll content of forage sorghum. International Journal of Biosciences, 6(4):157-164.

Moosavi, S.G. (2012). The effect of water deficit stress and nitrogen fertilizer levels on morphology traits, yield and leaf area index in maize. Pak. J. Bot., 44: 1351-1355.

Nassar, M. A. and K. F. El-Sahhar, (1998). Botanical preparations and microscopy (Microtechnique). Academic Bookshop, Dokki, Giza, Egypt, 219 pp. (In Arabic).

Nassar Rania, M.A.; A.M. Yasser and Dalia, M.A. Nassar, (2011). Effect of foliar spray with active yeast extract on morphological, anatomical and yield charactreristics of kidney bean (Phaseolus vulgaris L.) Australian Journal of basic and Applied Science, 5(5): 1071-1079.

Nazar, R.; N. Iqbal; S. Syeed and N. A. Khan, (2011). Salicylic acid alleviates decreases in photosynthesis under salt stress by enhancing nitrogen and sulfur assimilation and antioxidant metabolism differentially in two mung bean cultivars. J. Plant Physiol., 168:807-815.

Noreen, S.; M. Ashraf; M. Hiussain and A.J. Amer, (2009). Exogenous application of salycilic acid enhances antioxidative capacity in salt stressed sunflower (Helianthus annuus L.), Pak. J. Bot., 41: 473-479.

O'Mahony, M., (1986). Sensory evaluation of food: Statistical Methods and Procedures. CRC Press, pp. 487.

Orabi, S.A.; S.R. Salman and M.A.F. Shalaby, (2010). Increasing resistance to oxidative in cucumber (Cucumis sativus L.) plants by exogenous application of salicylic acid and paclobutrazol. World J. Agric. Sci., 6(3): 252-259.

Petrov, P. I.; K. V. Kocheva; A. S. Petrova and G. I Georgive, ( 2012). Ion leakage and leaf anatomy of barley plant subjected to dehydration. Genetics and plant physiology, 2(1 -2):15-23

Reda, F.M., (2007). Morphological, anatomical and physiological studies on (Senna occidentalis L.) link plants grown under stress of different levels of salinity in irrigation water. Journal of Agricultural Sciences, 32. Mansoura University, pp. 8301-8314

Sadeghipour, O. and P. Aghaei, (2012) Impact of exogenous salicylic acid application on some traits of common bean (Phaseolus vulgaris I.) under water stress conditions, Int. J. Agric. Crop. Sci., 4 (11), 685-690.

Siddiqui, H. M.; M. Y. Al-Khaishany; M. A. Al-Qutami; M. H. Al-Whaibi,; A. Grover; H. M. Ali; Mona, S. Al-Wahibi and Najat, A. Bukhari, (2015). Response of different genotypes of Faba bean plant to drought stress, Int. J. Mol. Sci., 16:10214-10227.

Singh, R.; A. Hemantaranjan and P. K. Patel, (2015). Salicylic acid improves salinity tolerance in field pea (Pisum sativum L.) by intensifying antioxidant defense system and preventing salt-induced nitrate reductase (NR) activity loss, Legume Research, 38(2): 202-208 
Szalai, G.; T. Janda; E. Pa; Â. Idi and Z. Szigeti, (1996). Role of light in postchilling symptoms in maize. J. Plant Physiol., 148: 378-383.

Wang, W.; B. Vinocur and A. Altman. (2003). Plant responses to drought, salinity and extreme temperatures: towards genetic engineering for stress tolerance. Planta. 218:1-14.

Yang, H.; H. Li; L. Q. Rao; G. Y. Long; G. R. Shi and G. P. Peng, (2013). Effcts of exogenous $A B A$ on antioxidant enzymes in detached citrus leaves treated by rapid freezing. African Journal of Biotechnology, 10: 9779-9785.

Zhang, L.; M. Gao; J. Hu; X. Zhang; K. Wang and M. Ashraf, (2012). Modulation role of abscisic acid (ABA) on growth, water relations and glycinebetaine metabolism in two maize (Zea mays L.) cultivars under drought stress, Int. J. Mol. Sci., 13, 3189-3202.

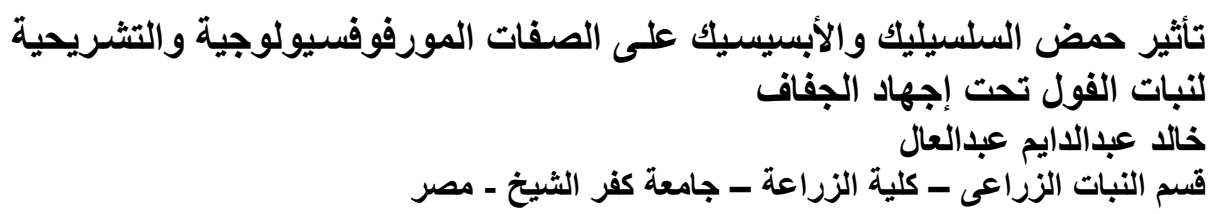

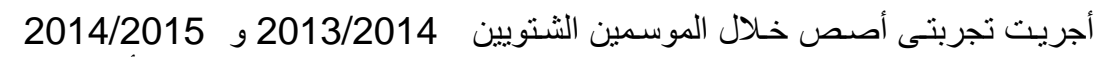

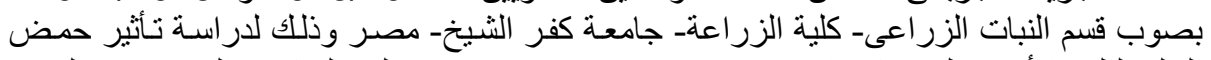

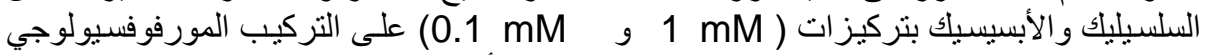

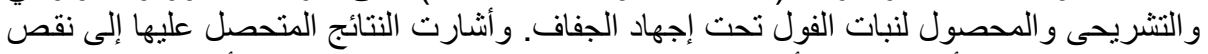

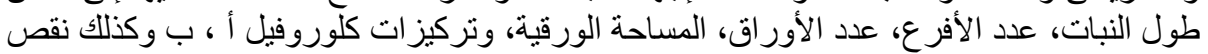

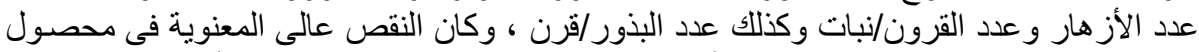

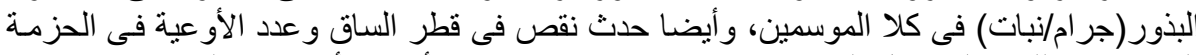

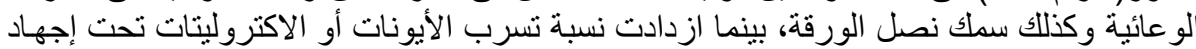

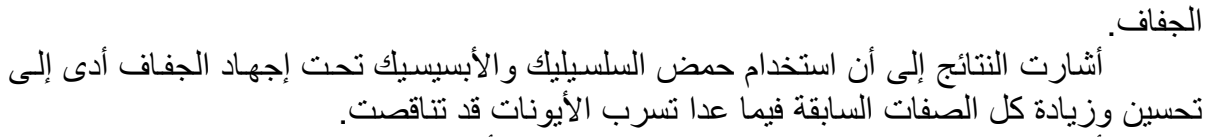

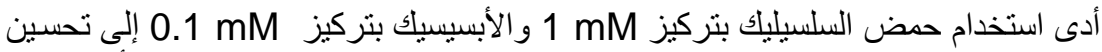

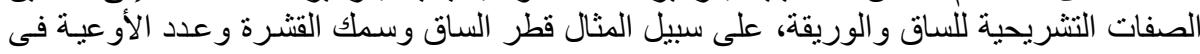

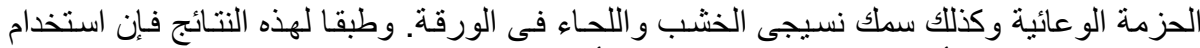

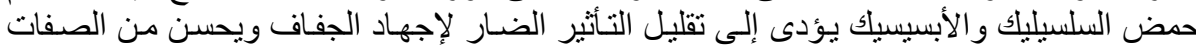

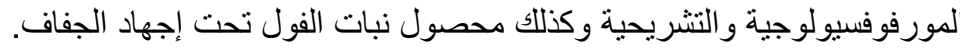

